Article

\title{
Evaluation of the Toxicity on Lung Cells of By-Products Present in Naphthalene Secondary Organic Aerosols
}

\author{
Yuri Lima de Albuquerque ${ }^{1} \mathbb{D}$, Emmanuelle Berger ${ }^{1}$, Sophie Tomaz ${ }^{2}$, Christian George ${ }^{2}$ (D) and Alain Géloën ${ }^{1, *}$ \\ 1 UMR Ecologie Microbienne, Université Claude Bernard Lyon 1, 69622 Villeurbanne, France; \\ yuri-mateus.lima-de-albuquerque@univ-lyon1.fr (Y.L.d.A.); emmanuelle.danty@univ-lyon1.fr (E.B.) \\ 2 Univ Lyon, Université Claude Bernard Lyon 1, 69100 Villeurbanne, France; sophie.tomaz@inrs.fr (S.T.); \\ christian.george@ircelyon.univ-lyon1.fr (C.G.) \\ * Correspondence: alain.geloen@insa-lyon.fr
}

check for updates

Citation: Lima de Albuquerque, Y.; Berger, E.; Tomaz, S.; George, C.; Géloën, A. Evaluation of the Toxicity on Lung Cells of By-Products Present in Naphthalene Secondary Organic Aerosols. Life 2021, 11, 319. https:// doi.org/10.3390/life11040319

Academic Editor: João Rodrigues

Received: 25 February 2021

Accepted: 5 April 2021

Published: 6 April 2021

Publisher's Note: MDPI stays neutral with regard to jurisdictional claims in published maps and institutional affiliations.

Copyright: (c) 2021 by the authors. Licensee MDPI, Basel, Switzerland. This article is an open access article distributed under the terms and conditions of the Creative Commons Attribution (CC BY) license (https:/ / creativecommons.org/licenses/by/ $4.0 /)$.

\begin{abstract}
In 2018, seven million people died prematurely due to exposure to pollution. Polycyclic aromatic hydrocarbons (PAHs) are a significant source of secondary organic aerosol (SOA) in urban areas. We investigated the toxic effects of by-products of naphthalene SOA on lung cells. These byproducts were 1,4-naphthoquinone (1,4-NQ), 2-hydroxy-1,4-naphthoquinone (2-OH-NQ), phthalic acid (PA) and phthaldialdehyde (OPA). Two different assessment methodologies were used to monitor the toxic effects: real-time cell analysis (RTCA) and the Holomonitor, a quantitative phase contrast microscope. The chemicals were tested in concentrations of 12.5 to $100 \mu \mathrm{M}$ for $1,4-\mathrm{NQ}$ and 1 to $10 \mathrm{mM}$ for 2-OH-NQ, PA and OPA. We found that 1,4-NQ is toxic to cells from 25 to $100 \mu \mathrm{M}$ (EC50: $38.7 \mu \mathrm{M} \pm 5.2$ ); $2-\mathrm{OH}-\mathrm{NQ}$ is toxic from 1 to $10 \mathrm{mM}$ (EC50: $5.3 \mathrm{mM} \pm 0.6$ ); PA is toxic from 5 to $10 \mathrm{mM}$ (EC50: $5.2 \mathrm{mM} \pm 0.3$ ) and OPA is toxic from 2.5 to $10 \mathrm{mM}$ (EC50: $4.2 \mathrm{mM} \pm 0.5)$. Only 1,4-NQ and OPA affected cell parameters (migration, motility, motility speed and optical volume). Furthermore, 1,4-NQ is the most toxic by-product of naphthalene, with an EC50 value that was one hundred times higher than those of the other compounds. RTCA and Holomonitor analysis showed a complementarity when studying the toxicity induced by chemicals.
\end{abstract}

Keywords: PAHs; secondary organic aerosols; RTCA; Holomonitor; naphthoquinone; A549

\section{Introduction}

In 2010, the World Health Organization (WHO) expressed concerns regarding the effects of several air pollutants on health [1]. In 2018, the WHO estimated that 7 million people suffered premature death caused by exposure to fine particles in polluted air. These particles can penetrate deep into the lungs and cardiovascular systems, causing diseases including stroke, heart disease, lung cancer, chronic obstructive pulmonary diseases and respiratory infections, including pneumonia [2,3].

Naphthalene, a ubiquitous polycyclic aromatic hydrocarbon (PAH), is one of the several air pollutants that affect the human health [1]. Naphthalene is a semi-volatile organic compound (SVOC) according to the U.S. Environmental Protection Agency classification [4], and it has a series of anthropogenic sources, such as chemical industries, gasoline evaporation or oil burning, leading locally to acute exposures [1,5]. In urban areas, vehicle emissions represent the most important source, but naphthalene is also present in the smoke of cigarettes [6]. Once in the air, naphthalene undergoes atmospheric oxidation, mainly by reacting hydroxyl radicals $(\bullet \mathrm{OH})$, and thereby acts as a precursor of secondary organic aerosols (SOA). These ultrafine particles have a complex chemical composition and therefore possess chemical complexity and yield products such as 1,4-naphthoquinone (1,4-NQ), 2-hydroxy-1,4 naphthoquinone (2-OH-NQ), phthalic acid (PA), phthaldialdehyde (OPA) [7-10].

Studies on lung cell lines showed that 1,4-naphthoquinone (1,4-NQ) is toxic [11]. Quinones are a class of organic compounds with chemical properties allowing them to 
interact with biological targets by forming covalent bonds and transferring electrons in oxidation-reduction reactions. Among all quinones, 1,4-NQ and its secondary products are of particular interest because of their occurrence as natural chemicals and/or products $[12,13]$. These compounds have diverse pharmacological properties, such as antimicrobial [14], antiviral [15], antiprotozoal and anthelmintic [16,17], also presenting cytotoxic effects on cancer cell lines [18]. Moreover, 2-hydroxy-1,4-naphthoquinone (lawsone) (2-OH-NQ), a photochemical reaction product of 1,4-naphthoquinones, can also be extracted from the leaves of Lawsonia inermis. It is one of the most widely used skin dyes, commonly known as Henna. It has been intensively utilized for many years in the biology, medicine, agriculture and industries as a skin dye and antifungal [19,20]. Regarding its toxicity, Sauriasari et al. concluded that lawsone is not mutagenic, but it is toxic to cells in a dose-dependent manner [21].

Phthalic acid (PA) is a benzene dicarboxylic acid with no reports on its toxic effects on the respiratory system [22]. Phthaldialdehyde (OPA) is a dialdehyde used mostly as a fluorescent marker or a disinfectant, but in vivo experiments proved OPA to be toxic to the respiratory systems of rats [23-26].

To study the cytotoxic effects of chemicals, the colorimetric MTT (tetrazolium salt (3[4,5-dimethylthiazol-2-yl]-2,5-diphenyltetrazolium bromide)) assay, is widely used. However, this technique only shows the end-points and not the stage of cell proliferation [27]. Nowadays, more sophisticated approaches are available. Real-time cell analysis (RTCA) allows the label-free and real-time monitoring of cell proliferation and viability. It monitors the viability of cultured cells using electrical impedance. The continuous monitoring of cell proliferation makes it possible to recognize different perturbations of cell viability, such as toxicity (cell death) and reduced proliferation (cell cycle arrest). Technical improvements also allow the creation of 3D reconstructive images of cells and the measurement of the structural and behavioral parameters of cells [28,29]. Similarly, the Holomonitor microscope performs label-free and non-invasive measurements with the use of a low-power laser. Cell structural (area, optical volume and perimeter) and behavioral (motility, motility speed and migration) parameters can be measured in real time with this microscope.

Bearing in mind the importance of ultrafine particles derived from PAH photooxidation in urban areas, we studied here the toxicity of the main by-products of naphthalene SOA using the abovementioned new methodologies to determine their impacts on lung cells.

\section{Materials and Methods}

\subsection{Cell Culture}

Human carcinoma A549 cells (provided by ATCC, Massanas, VA, USA) were grown in Dulbecco's Modified Eagle's Medium with low glucose $(1 \mathrm{~g} / \mathrm{L})$ containing $10 \%$ fetal calf serum (DMEM 10\% FCS, PAA Laboratories, Toronto, ON, Canada) with the addition of streptomycin plus penicillin (100 units/mL; Sigma-Aldrich, St. Quentin Fallavier, France). The cells were trypsinized by $0.05 \%$ trypsin (Sigma-Aldrich, St. Quentin Fallavier, France) and the cell concentration was measured using a Sceptor pipette (Millipore, Burlington, MA, USA). Cell cultures were conducted from passage 3 to 7.

\subsection{Naphthalene SOA By-Products}

The chemical composition of PAH-derived SOA is quite complex, with hundreds to thousands of compounds being present. To simplify our approach, and to allow a molecular approach to the toxic response of these particles, we investigated the impact of by-products mimicking naphthalene-derived aerosols [7-10,30].

The chemicals investigated in this study were 1,4-naphthoquinone (1,4-NQ), 2-hydroxy1,4 naphthoquinone (2-OH-NQ), phthalic acid (PA) and phthaldialdehyde (OPA), purchased from Sigma-Aldrich (St. Quentin Fallavier, France). All chemicals were dissolved in DMSO and further diluted in Dulbecco's Modified Eagle's Medium with low glucose $(1 \mathrm{~g} / \mathrm{L})$ containing $10 \%$ fetal calf serum (DMEM 10\% FCS, PAA Laboratories, Toronto, ON, 
Canada) with the addition of streptomycin plus penicillin (100 units/mL; Sigma Aldrich, St-Louis, MO, USA) with $0.1 \%$ of DMSO (Sigma Aldrich, St-Louis, MO,USA) in the end.

Cells were exposed to different concentrations of the compounds when the cell index reached the value of 1.0. The concentrations tested for 1,4-NQ were 12.5, 25, 50 and $100 \mu \mathrm{M}$. The concentrations for 2-OH-NQ, phthalic acid (PA) and phthaldialdehyde (OPA) were 1, $2.5,5,7.5$ and $10 \mathrm{mM}$.

\subsection{Measurements of Cytotoxicity \\ 2.3.1. Effects on Cell Proliferation}

Real-time cell analysis system (RTCA) (Agilent, Santa Clara, CA, USA) measures cell indexes resulting from cell surface occupancy, taking into consideration cell number, cell size and adhesion force. In the case of cytotoxicity, a decrease in cell index can result from a decreased cell number (=cell death), a decrease in cell adhesion or a decrease in cell surface. Cell surface and number can be measured by the Holomonitor. RTCA results are represented as delta cell indexes (differences in final - initial cell index $=$ time of treatment). In order to measure the cytotoxic response of A549 cells in real time, cells were seeded on gold microelectrodes embedded at the bottom of 96-well microplates (E-plates; Roche Diagnostics, Basel, Switzerland) at a density of 2500 cells/well. The impedance was recorded at 15 -min intervals for $24 \mathrm{~h}$ in a standard $37^{\circ} \mathrm{C}$ cell culture incubator with $5 \%$ $\mathrm{CO}_{2}$. The EC50 of each compound was calculated using the RTCA data with Excel.

\subsubsection{Quantitative Phase Imaging}

Quantitative phase imaging was performed using the Holomonitor M4 digital holographic cytometer (DHC) from Phase Holographic Imaging (PHI, Lund, Sweden). The platform was housed in a standard $37{ }^{\circ} \mathrm{C}$ cell culture incubator with $5 \% \mathrm{CO}_{2}$. The behavioral (motility, motility speed and migration) and structural (area, optical volume and perimeter) parameters were measured from 3D reconstructed images obtained for $10 \mathrm{~h}$ with intervals of $5 \mathrm{~min}$ between measurements.

\subsection{Statistical Analysis}

Data presented are representative of experiments performed at least in triplicate, as mean values \pm SEM for RTCA and Holomonitor $(n=3$ for 96- and $n=8$ for E96 wells). Statistical analysis was performed with StatView 4.5 software (Abacus Corporation, Baltimore, MD, USA) for Windows. Data were analyzed using one-way ANOVA followed by Fisher's protected least significance difference (PLSD) post hoc test. Significance level was accepted at $p<0.05$.

\section{Results}

\subsection{Effects of Naphthalene SOA By-Products on A549 Proliferation}

To determine whether the by-products of naphthalene SOA are toxic, A549 cells were exposed to increasing concentrations of 1,4-NQ (12.5, 25, 50 and $100 \mu \mathrm{M}), 2-\mathrm{OH}-\mathrm{NQ}, \mathrm{PA}$ and OPA $(1,2.5,5,7.5$ and $10 \mathrm{mM})$.

Figure 1 shows the evolution of cell index given by RTCA of A549 cells in response to increasing concentrations of each by-product of naphthalene. We found that 1,4-NQ killed the cells at concentrations of 50 and $100 \mu \mathrm{M}$, while at $25 \mu \mathrm{M}$, it promoted toxicity by decreasing the cell index. At $10 \mu \mathrm{M}, 1,4-\mathrm{NQ}$ did not show any sign of toxicity, thus not differing from the control (Figure 1A). Furthermore, 2-OH-NQ was toxic to cells at every tested concentration, promoting cell death at $10 \mathrm{mM}$ and decreasing the cell index at $1,2.5,5$ and $7.5 \mathrm{mM}$ (Figure 1B). PA killed the cells at $10 \mathrm{mM}$. At 5 and $7.5 \mathrm{mM}$, it caused a decrease in cell index, while at 1 and $2.5 \mathrm{mM}$, no differences from the control were observed (Figure 1C). OPA was toxic from 2.5 to $10 \mathrm{mM}$, significantly decreasing the cell index. At the concentration of $1 \mathrm{mM}$, it was not toxic to cells (Figure 1D). 

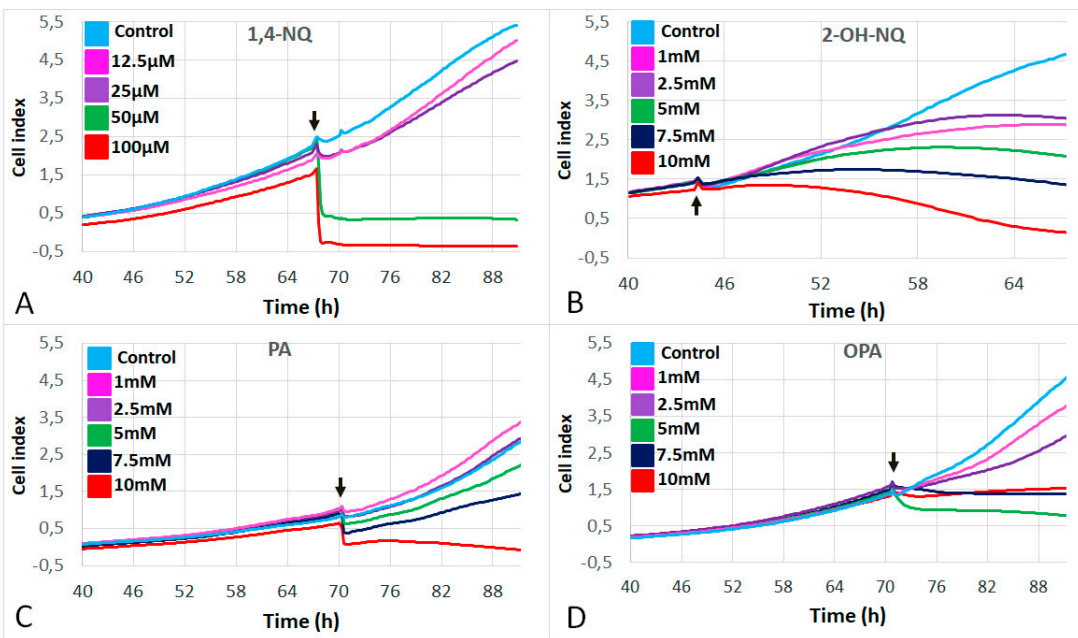

Figure 1. Dose-response curves of A549 cell proliferation in response to (A) 1,4-naphthoquinone (1,4-NQ) at $12.5 \mu \mathrm{M}$ (pink), $25 \mu \mathrm{M}$ (purple), $50 \mu \mathrm{M}$ (green), $100 \mu \mathrm{M}$ (red) and control (light blue); (B) 2-hydroxy-1,4-naphthoquinone (2-OH-NQ); (C) phthalic acid (PA); and (D) phthaldialdehyde (OPA). For (B-D): $1 \mathrm{mM}$ (pink); 2.m (purple); $5 \mathrm{mM}$ (green); $7.5 \mathrm{mM}$ (blue); and $10 \mathrm{mM}$ (red) and control (light blue). Black arrows: time of addition of the treatment (TRT).

Figure 2 represents the EC50 for each chemical. They were calculated from the mean of the delta cell indexes obtained from at least three repetitions. Results are $38.7 \pm 5.2 \mu \mathrm{M}$ for 1,4-NQ; $5.3 \pm 0.6 \mathrm{mM}$ for 2-OH-NQ; $5.2 \pm 0.3 \mathrm{mM}$ for PA; and $4.2 \pm 0.5 \mathrm{mM}$ for OPA.
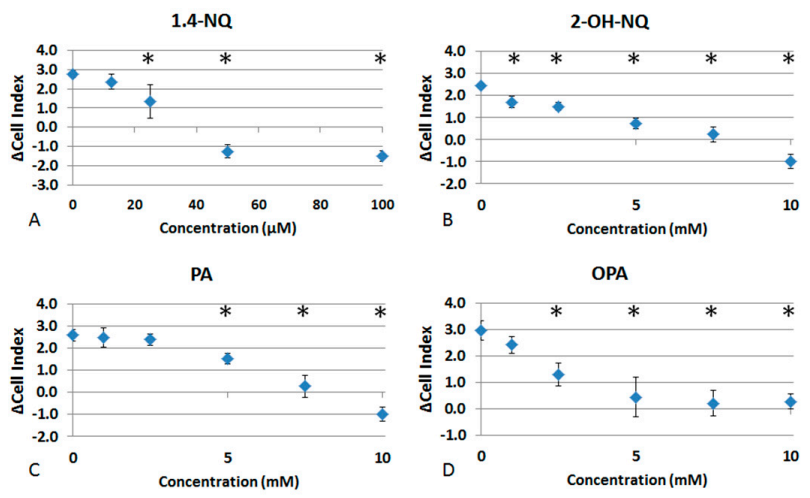

Figure 2. Delta cell index in response to increasing concentrations of (A) 1,4-naphthoquinone (1,4-NQ); (B) 2-hydroxy, 1,4-naphthoquinone (2-OH-NQ); (C) phthalic acid (PA); and (D) phthaldialdehyde (OPA). Asterisks indicate significant differences at $p<0.05$ when compared to control.

\subsection{Effects of Naphthalene SOA By-Products on A549 Behavioral and Structural Parameters}

To determine whether the by-products of naphthalene SOA alter the structure and behavior of cells, A549 cells were exposed to concentrations corresponding to the EC50 observed for cell proliferation, i.e., 1,4-NQ $(50 \mu \mathrm{M})$, 2-OH-NQ, PA and OPA (5 mM). Cells were monitored by means of the Holomonitor for 10 hours post-exposure to the chemicals.

Firstly, 1,4-NQ impacted the optical volume, migration, motility and motility speed of the cells, while their area and perimeter did not differ from the control. Optical volume showed a significant decrease when compared to the control in the last $2 \mathrm{~h}$ of the experiment (Figure 3A-C). Migration of cells treated with 1,4-NQ showed a significant decrease when compared to the control after $5 \mathrm{~h}$, as did motility and motility speed after $3 \mathrm{~h}$ (Figure 3D-F). The curve for migration, differing from the control, did not evolve during the experiment. Motility, however, slightly increased throughout the experiment but remained much lower than the control. 


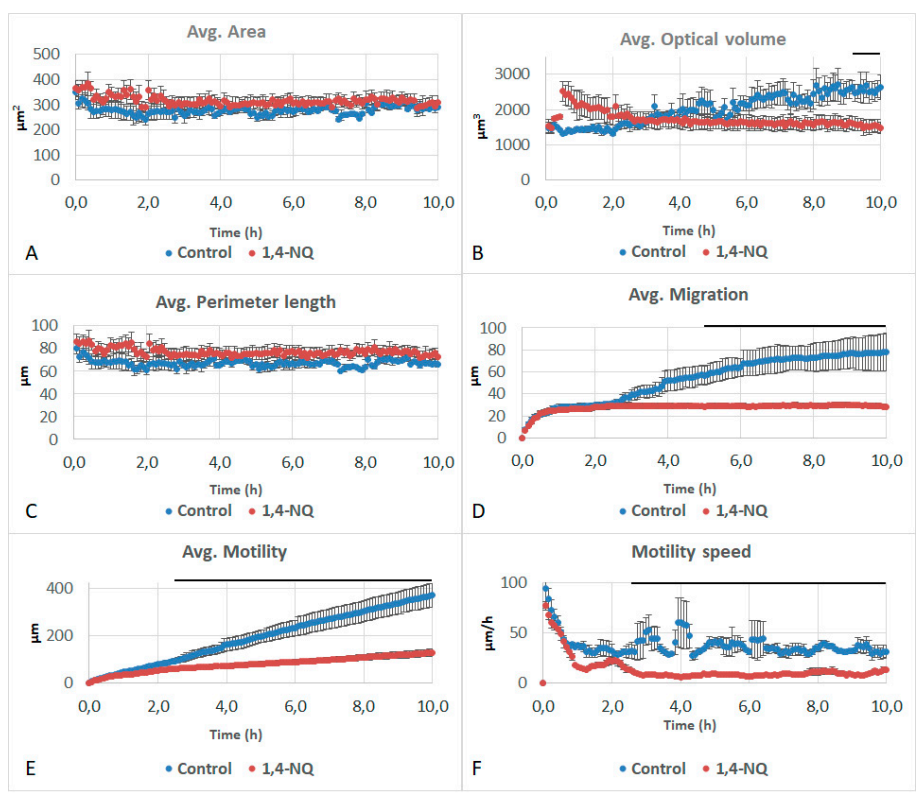

Figure 3. Effects of $50 \mu \mathrm{M}$ of 1,4-naphthoquinone (1,4-NQ) on (A) area, (B) optical volume, (C) perimeter length, (D) migration, (E) motility and (F) motility speed of A549 cells. Black lines above the curves indicate significant differences at $p<0.05$ between 1,4-NQ and control.

Furthermore, 2-OH-NQ and PA did not affect any of the studied parameters (Figures 4 and 5). OPA impacted the optical volume, migration, motility and motility speed of the cells. While area and perimeter did not differ from the control (Figure 6A,C), optical volume showed a significant reduction over the entire experiment, when compared to the control (Figure 6B). After $5 \mathrm{~h}$, migration showed a significant decrease, as did motility after $1 \mathrm{~h}$ and motility speed after $45 \mathrm{~min}$ (Figure 6D-F). Optical volume and migration remained constant throughout the experiment. Motility increased slightly during the experiment, but at a slower pace than the control.

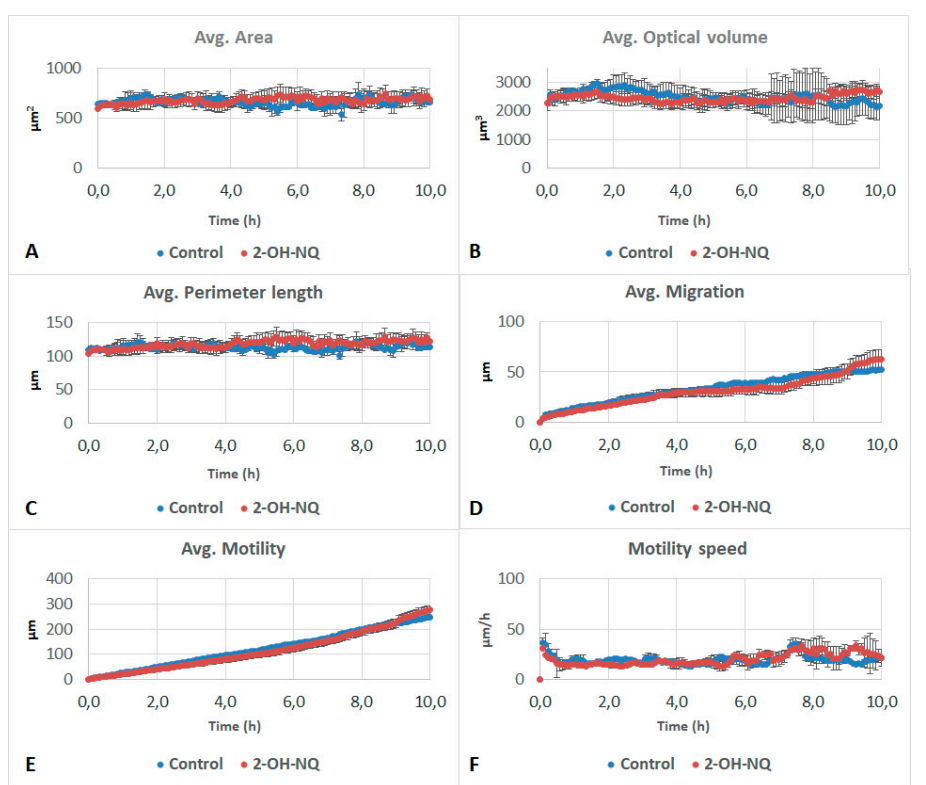

Figure 4. Effects of $5 \mathrm{mM}$ of 2-hydroxy-1,4-naphthoquinone (2-OH-NQ) on (A) area, (B) optical volume, (C) perimeter length, (D) migration, (E) motility and (F) motility speed of A549 cells. No significant differences were observed in these parameters. 


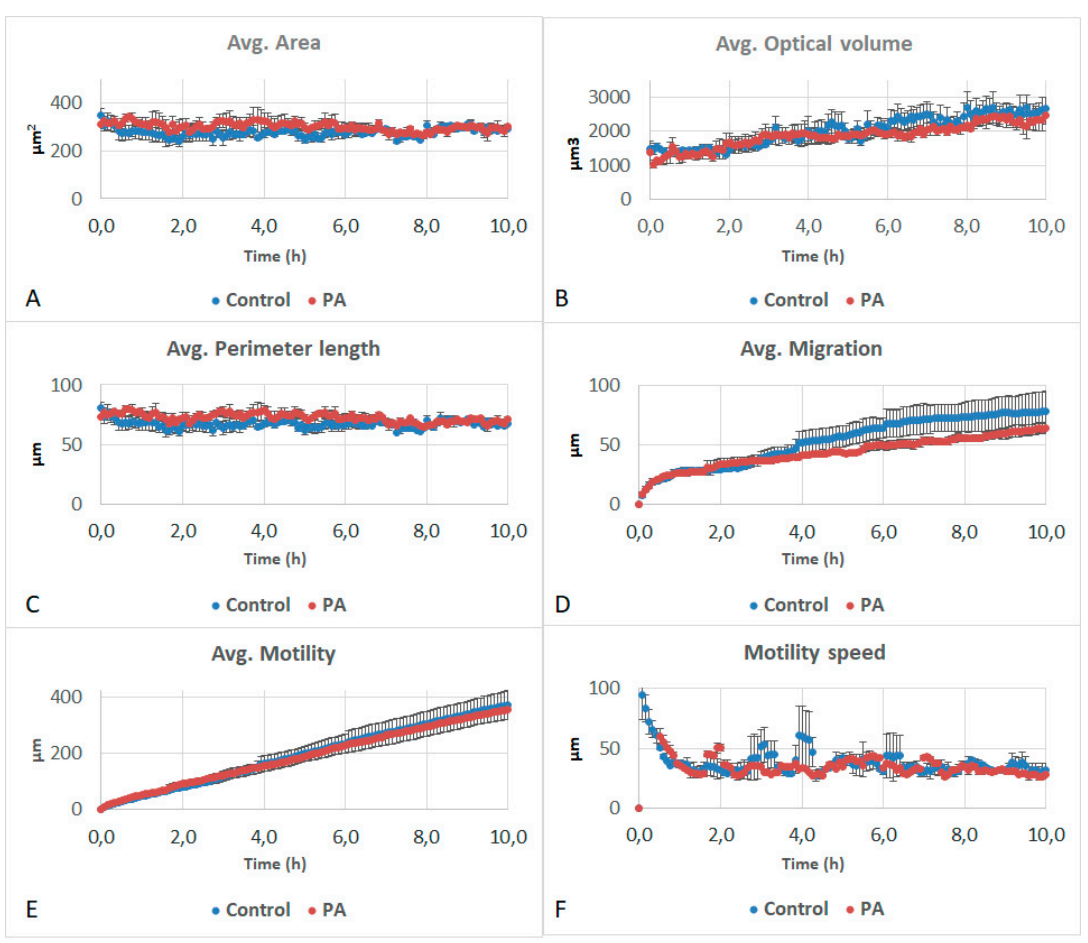

Figure 5. Effects of $5 \mathrm{mM}$ of phthalic acid (PA) on the (A) area, (B) optical volume, (C) perimeter length, (D) migration, (E) motility and (F) motility speed of A549 cells. No significant differences were observed in these parameters.

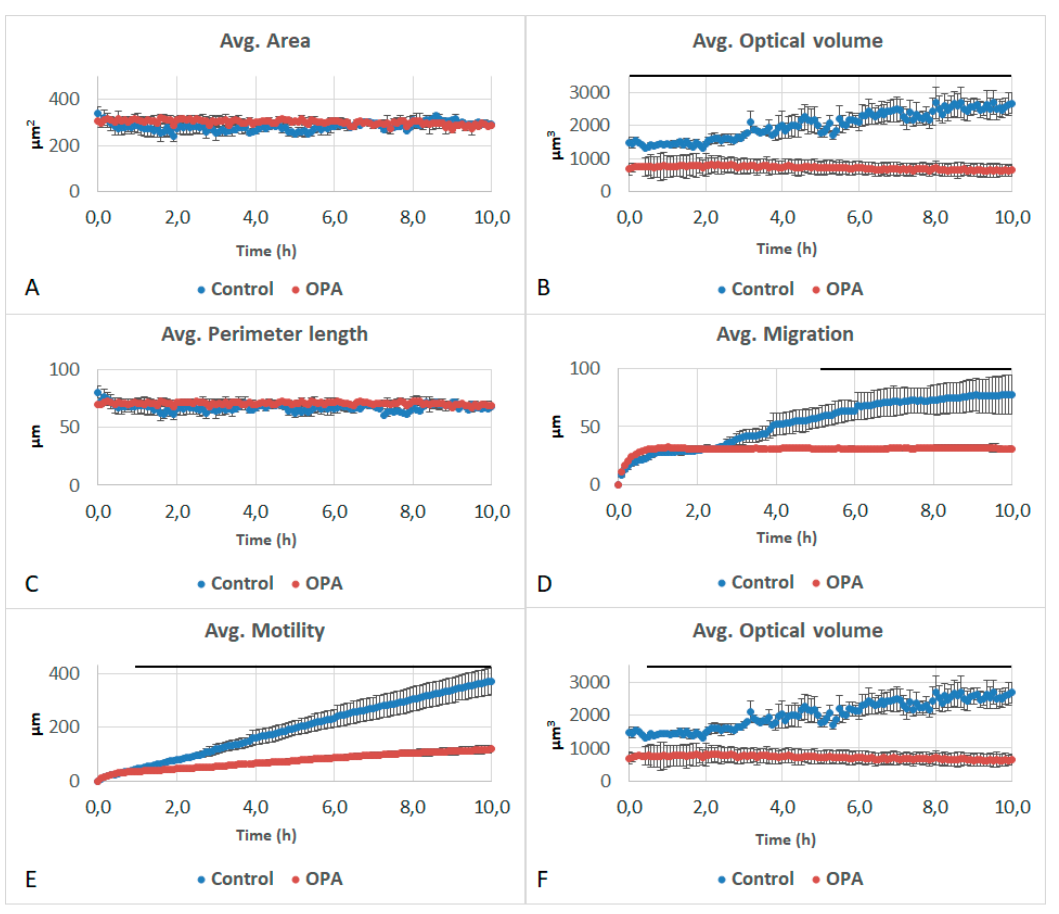

Figure 6. Effects of $5 \mathrm{mM}$ of phthaldialdehyde (OPA) on (A) area, (B) optical volume, (C) perimeter length, (D) migration, (E) motility and (F) motility speed of A549 cells. Black lines above the curves represent significant differences at $p<0.05$ between OPA and the control.

\section{Discussion}

Although air pollution is a threat to human health, there are still major uncertainties regarding the nature of the compounds triggering health diseases. In particular, in 
populated urban areas, exposure to secondary aerosols arising from the photo-oxidation of PAHs is significant. In the present study, the toxicity of four chemicals derived from naphthalene SOA was measured using an RTCA biosensor. The dose-response curves show that $1,4 \mathrm{NQ}$ is by far the most toxic $(\mathrm{EC} 50=38.7 \mu \mathrm{M})$ compared to 2-OH-NQ, PA and OPA (EC50 $=5.3,5.2$ and $4.2 \mathrm{mM}$, respectively), by an order of magnitude of 100 . Babich \& Stern reported that substitution with a hydroxyl group in the quinoid ring of 1,4-NQ, thus creating 2-OH-NQ, occasioned a decrease in its cytotoxicity, corroborating the present results [31]. Shang et al. found that 1,4-NQ had a dose-response toxic effect on A549 cells from 2.5 to $50 \mu \mathrm{M}$ [32]. While working with 2-methyl-1,4-naphthoquinone, a synthetic form of vitamin $\mathrm{K}\left(\mathrm{K}_{3}\right)$ that shares similarities with 1,4-NQ, Shang et al. stated that its EC50 on A549 cells is $46.8 \mu \mathrm{M}$, a value similar to the EC50 reported in the present results $[33,34]$. Previous studies also suggested that 1,4-NQ is toxic to cells by modulating the metabolic pathways through a combined effect of oxidative stress and energy depletion [33,35,36]. It is also known that 1,4-NQ can interact with glutathione, thus modifying this compound and causing its depletion in cells [34].

Quinones are known to cause microtubule disarrangement and to induce the formation of reactive oxygen species (ROS), damaging the cell membranes and the DNA (clastogenicity); the latter is also damaged by the inhibition, caused by 1,4-NQ, of the human topoimerase II $\alpha$ enzyme, an enzyme responsible for maintaining the DNA topology $[11,33,34,37-39]$. Complementary to the formation of ROS, quinones are known to have inflammatory potential, by upregulating inflammatory genes such as IL-6, IL-8, TNF- $\alpha$, Cyp1a1 and HO-1 [40].

To better determine the effects of the different chemicals on cell structure and behavior, we used the Holomonitor microscope. To identify their cellular effects, compounds were tested at concentrations corresponding to their EC50. The cell index produced by RTCA depends on the surface occupied by the cell and their adhesion strength. The surface occupied by cells results from cell number and cell size. The Holomonitor measures different cell parameters, such as surface, perimeter and volume. The fact that the cell index was significantly decreased at the EC50 for 1,4-NQ and OPA, but the area and perimeter of cells were not changed, points out an effect on cell adhesion; both chemicals decreased the optical volume of cells without affecting cell perimeter and area.

The Holomonitor also produces effects on cell behavior, such as motility, motility speed and migration. Firstly, 1,4-NQ and OPA significantly decreased all these parameters while 2-OH-NQ and PA did not alter them. Cell migration is intrinsically connected to the upregulation of the signal transducer and activator of transcription 3 (STAT-3) [41]. Quinones derived from 1,4-NQ are recognized for decreasing the expression levels of this protein [42], which could explain the decrease in all behavioral parameters associated with 1,4-NQ. It is also interesting to note that both 1,4-NQ and OPA induced a decrease in the migration, motility and motility speed.

Results from the literature are divergent on the toxicity of PA. Ema et al. observed that this chemical is not toxic to pregnant rats and their litter, while Kwack \& Lee stated that it decreased the viability of testicle cells by $40 \%$ at $100 \mathrm{mM}$, a concentration $10 \times$ higher than the one that caused cell death in our experiment [43,44]. The present study is the first to assess the toxic effects of PA on proliferating lung cells, which is of extreme importance, since, as a by-product of naphthalene, it is present in the air in urban areas.

Phthaldialdehyde is used as a common endoscope disinfectant, and there have been reported cases of severe skin and mucous membrane damage of the lip, tongue, pharynx and esophagus areas that were attributed to inadequate washing after the sterilization of a transesophageal echo device with OPA $[45,46]$. In the present study, OPA decreased the cell index and the optical volume, migration, motility and motility speed when compared to a control. In vivo studies showed that OPA caused fibrosis, hyperplasia, chronic active inflammation and squamous metaplasia in the lung, causing even histiocytic cellular infiltration in the alveolus. However, none of these lesions are known to cause a decrease 
in the pneumocyte volume or migration parameters; thus, the question regarding the mechanisms that OPA uses to cause these effects remains unanswered.

When comparing RTCA and the Holomonitor, both methods are real-time, without labelling, and useful for assessing the toxicity of all components. However, as RTCA produces an impedance value reflecting cell proliferation, it can be affected by cell surface and adhesion strength. In this manner, the Holomonitor brings a complementary method of determining the impact of a chemical on cells.

\section{Conclusions}

In conclusion, 1,4-NQ is the most toxic by-product of naphthalene, with an EC50 value that is one hundred times higher than those of other compounds, inducing structural and behavioral alterations in A549 cells. Despite their similar EC50 values on RTCA, 2-OH-NQ and PA showed no alteration in cell parameters, while OPA significantly altered optical volume, motility, motility speed and migration. The present study highlights the perfect complementarity of RTCA and the Holomonitor microscope to study alterations induced by chemicals.

Author Contributions: Conceptualization, Y.L.d.A., C.G. and A.G.; methodology, Y.L.d.A., E.B. and A.G.; validation, C.G. and A.G.; formal analysis, Y.L.d.A. and A.G.; investigation, Y.L.d.A., E.B. and A.G.; resources, E.B., S.T., C.G. and A.G.; data curation, Y.L.d.A. and A.G.; writing-original draft preparation, Y.L.d.A. and A.G.; writing-review and editing, Y.L.d.A., C.G. and A.G.; visualization, Y.L.d.A., E.B. and A.G.; supervision, C.G. and A.G.; project administration, A.G.; funding acquisition, C.G. and A.G. All authors have read and agreed to the published version of the manuscript.

Funding: This research was funded by the University of Lyon through the Breakthrough Grant, WANTED.

Conflicts of Interest: The authors declare no conflict of interest. The funders had no role in the design of the study; in the collection, analyses, or interpretation of data; in the writing of the manuscript, or in the decision to publish the results.

\section{References}

1. Buckpitt, A.; Kephalopoulos, S.; Koistinen, K.; Kotzias, D.; Morawska, L.; Sagunski, H. Naphthalene. In WHO Guidelines for Indoor Air Quality: Selected Pollutants; World Health Organization: Geneva, Switzerland, 2010. Available online: https: //www.ncbi.nlm.nih.gov/books/NBK138704/ (accessed on 24 February 2021).

2. Du, Y.; Xu, X.; Chu, M.; Guo, Y.; Wang, J. Air Particulate Matter and Cardiovascular Disease: The Epidemiological, Biomedical and Clinical Evidence. J. Thorac. Dis. 2016, 8, E8-E19. [CrossRef]

3. World Health Organization. 9 Out of 10 People Worldwide Breathe Polluted Air, but More Countries Are Taking Action. Available online: https:/ / www.who.int/news/item/02-05-2018-9-out-of-10-people-worldwide-breathe-polluted-air-but-morecountries-are-taking-action (accessed on 24 February 2021).

4. US Enviromental Protection Agency. Compendium Method TO-14A. Available online: https://www3.epa.gov/ttnamti1/files/ ambient/airtox/to-14ar.pdf (accessed on 24 February 2021).

5. Menezes, H.C.; Paulo, B.P.; Costa, N.T.; Cardeal, Z.L. New Method to Determination of Naphthalene in Ambient Air Using Cold Fiber-Solid Phase Microextraction and Gas Chromatography-Mass Spectrometry. Microchem. J. 2013, 109, 93-97. [CrossRef]

6. US Health and Human Services. Toxicological Profile for Naphthalene, 1-methylnaphthalene, and 2-methylnaphthalene. Available online: https: / /www.atsdr.cdc.gov/ toxprofiles/tp67.pdf (accessed on 24 February 2021).

7. McConkey, B.J.; Hewitt, L.M.; Dixon, D.G.; Greenberg, B.M. Natural sunlight induced photooxidation of naphthalene in aqueous solution. Water Air Soil Pollut. 2002, 136, 347-359. [CrossRef]

8. Nishino, N.; Arey, J.; Atkinson, R. 2-Formylcinnamaldehyde Formation Yield from the OH Radical-Initiated Reaction of Naphthalene: Effect of $\mathrm{NO}_{2}$ Concentration. Environ. Sci. Technol. 2012, 46, 8198-8204. [CrossRef]

9. Huang, G.; Liu, Y.; Shao, M.; Li, Y.; Chen, Q.; Zheng, Y.; Wu, Z.; Liu, Y.; Wu, Y.; Hu, M.; et al. Potentially Important Contribution of Gas-Phase Oxidation of Naphthalene and Methylnaphthalene to Secondary Organic Aerosol during Haze Events in Beijing. Environ. Sci. Technol. 2019, 53, 1235-1244. [CrossRef] [PubMed]

10. Saxena, S.; Panchagnula, S.; Sanz, M.E.; Pérez, C.; Evangelisti, L.; Pate, B.H. Structural Changes Induced by Quinones: HighResolution Microwave Study of 1,4-Naphthoquinone. ChemPhysChem 2020, 21, 2579-2584. [CrossRef] [PubMed]

11. Gurbani, D.; Kukshal, V.; Laubenthal, J.; Kumar, A.; Pandey, A.; Tripathi, S.; Arora, A.; Jain, S.K.; Ramachandran, R.; Anderson, D.; et al. Mechanism of Inhibition of the ATpase Domain of Human Topoisomerase II $\alpha$ by 1,4-Benzoquinone, 1,2-Naphthoquinone, 1,4-Naphthoquinone, and 9,10-Phenanthroquinone. Toxicol. Sci. 2012, 126, 372-390. [CrossRef] 
12. Kumagai, Y.; Shinkai, Y.; Miura, T.; Cho, A.K. The Chemical Biology of Naphthoquinones and Its Environmental Implications. Annu. Rev. Pharmacol. Toxicol. 2012, 52, 221-247. [CrossRef]

13. De Sena Pereira, V.S.; Silva de Oliveira, C.B.; Fumagalli, F.; da Silva Emery, F.; da Silva, N.B.; de Andrade-Neto, V.F. Cytotoxicity, Hemolysis and in Vivo Acute Toxicity of 2-Hydroxy-3-Anilino-1,4-Naphthoquinone Derivatives. Toxicol. Rep. 2016, 3, 756-762. [CrossRef]

14. Sreelatha, T.; Kandhasamy, S.; Dinesh, R.; Shruthy, S.; Shweta, S.; Mukesh, D.; Karunagaran, D.; Balaji, R.; Mathivanan, N.; Perumal, P.T. Synthesis and SAR Study of Novel Anticancer and Antimicrobial Naphthoquinone Amide Derivatives. Bioorganic Med. Chem. Lett. 2014, 24, 3647-3651. [CrossRef]

15. da Costa, E.C.B.; Amorim, R.; da Silva, F.C.; Rocha, D.R.; Papa, M.P.; de Arruda, L.B.; Mohana-Borges, R.; Ferreira, V.F.; Tanuri, A.; da Costa, L.J.; et al. Synthetic 1,4-Pyran Naphthoquinones Are Potent Inhibitors of Dengue Virus Replication. PLoS ONE 2013, 8, e82504. [CrossRef] [PubMed]

16. Pinto, E.G.; Santos, I.O.; Schmidt, T.J.; Borborema, S.E.T.; Ferreira, V.F.; Rocha, D.R.; Tempone, A.G. Potential of 2-Hydroxy3-Phenylsulfanylmethyl-[1,4]-Naphthoquinones against Leishmania (L.) Infantum: Biological Activity and Structure-Activity Relationships. PLoS ONE 2014, 9, e105127. [CrossRef] [PubMed]

17. Lanfranchi, D.A.; Cesar-Rodo, E.; Bertrand, B.; Huang, H.-H.; Day, L.; Johann, L.; Elhabiri, M.; Becker, K.; Williams, D.L.; Davioud-Charvet, E. Synthesis and Biological Evaluation of 1\{,\}4-Naphthoquinones and Quinoline-5\{,\}8-Diones as Antimalarial and Schistosomicidal Agents. Org. Biomol. Chem. 2012, 10, 6375-6387. [CrossRef] [PubMed]

18. David, C.C.; Lins, A.C.S.; Silva, T.M.S.; Campos, J.F.; Silva, T.G.; Militão, G.C.G.; Camara, C.A. Synthesis and Cytotoxicity Evaluation of a Series of 3-Alkenyl-2-Hydroxy-1,4-Naphthoquinones Obtained by an Efficient Knoevenagel Condensation. J. Braz. Chem. Soc. 2019, 30, 8-18. [CrossRef]

19. Rudnicka, M.; Ludynia, M.; Karcz, W. A Comparison of the Effects of 1,4-Naphthoquinone and 2-Hydroxy-1,4-Naphthoquinone (Lawsone) on Indole-3-Acetic Acid (IAA)-Induced Growth of Maize Coleoptile Cells. Plant Growth Regul. 2018, 84, 107-122. [CrossRef]

20. Lozza, L.; Moura-Alves, P.; Domaszewska, T.; Lage Crespo, C.; Streata, I.; Kreuchwig, A.; Puyskens, A.; Bechtle, M.; Klemm, M.; Zedler, U.; et al. The Henna Pigment Lawsone Activates the Aryl Hydrocarbon Receptor and Impacts Skin Homeostasis. Sci. Rep. 2019, 9, 1-21. [CrossRef]

21. Sauriasari, R.; Wang, D.H.; Takemura, Y.; Tsutsui, K.; Masuoka, N.; Sano, K.; Horita, M.; Wang, B.L.; Ogino, K. Cytotoxicity of Lawsone and Cytoprotective Activity of Antioxidants in Catalase Mutant Escherichia Coli. Toxicology 2007, 235, 103-111. [CrossRef]

22. Phthalic Acid and Its Isomers (Isophthalic Acid and Terephthalic Acid) [MAK Value Documentation, 2009]. The MAK-Collection for Occupational Health and Safety; American Cancer Society: Atlanta, GA, USA, 2012; pp. 194-221. [CrossRef]

23. Smith, P.W.G.; Tatchell, A.R. Chapter VIII-Aromatic Carboxylic Acids; Pergamon: Oxford, UK, 1969; pp. 176-195. [CrossRef]

24. Lorz, P.M.; Towae, F.K.; Enke, W.; Jäckh, R.; Bhargava, N.; Hillesheim, W. Phthalic Acid and Derivatives. In Ullmann's Encyclopedia of Industrial Chemistry; Wiley-VCH: Weinheim, Germany, 15 July 2007. [CrossRef]

25. Catlin, N.R.; Willson, C.J.; Stout, M.; Kissling, G.E.; Waidyanatha, S.; Baker, G.L.; Hayden, B.K.; Wyde, M. Evaluation of the Respiratory Tract Toxicity of Ortho-Phthalaldehyde, a Proposed Alternative for the Chemical Disinfectant Glutaraldehyde. Inhal. Toxicol. 2017, 29, 414-427. [CrossRef]

26. National Center for Biotechnology Information. PubChem Compound Summary for CID 4807, o-Phthalaldehyde. Available online: https:/ / pubchem.ncbi.nlm.nih.gov/compound/o-Phthalaldehyde (accessed on 24 February 2021).

27. Masarik, M.; Gumulec, J.; Hlavna, M.; Sztalmachova, M.; Babula, P.; Raudenska, M.; Pavkova-Goldbergova, M.; Cernei, N.; Sochor, J.; Zitka, O.; et al. Monitoring of the Prostate Tumour Cells Redox State and Real-Time Proliferation by Novel Biophysical Techniques and Fluorescent Staining. Integr. Biol. 2012, 4, 672-684. [CrossRef]

28. Molder, A.; Sebesta, M.; Gustafsson, M.; Gisselson, L.; Wingren, A.G.; Alm, K. Non-Invasive, Label-Free Cell Counting and Quantitative Analysis of Adherent Cells Using Digital Holography. J. Microsc. 2008, 232, 240-247. [CrossRef] [PubMed]

29. Ke, N.; Wang, X.; Xu, X.; Abassi, Y.A. The XCELLigence System for Real-Time and Label-Free Monitoring of Cell Viability. In Mammalian Cell Viability: Methods and Protocols; Stoddart, M.J., Ed.; Humana Press: Totowa, NJ, USA, 2011; pp. 33-43. [CrossRef]

30. Brussol, C.; Duane, M.; Carlier, P.; Kotzias, D. Photo-Induced OH Reactions of Naphthalene and Its Oxidation Products on SiO 2 . Environ. Sci. Pollut. Res. 1999, 6, 138-140. [CrossRef] [PubMed]

31. Babich, H.; Stern, A. In Vitro Cytotoxicities of 1,4-Naphthoquinone and Hydroxylated 1,4-Naphthoquinones to Replicating Cells J. Appl. Toxicol. 1993, 13, 353-358. [CrossRef] [PubMed]

32. Shang, Y.; Fan, L.; Feng, J.; Lv, S.; Wu, M.; Li, B.; Zang, Y.S. Genotoxic and Inflammatory Effects of Organic Extracts from Traffic-Related Particulate Matter in Human Lung Epithelial A549 Cells: The Role of Quinones. Toxicol. Vitr. 2013, 27, 922-931. [CrossRef]

33. Shang, Y.; Zhang, L.; Jiang, Y.; Li, Y.; Lu, P. Airborne Quinones Induce Cytotoxicity and DNA Damage in Human Lung Epithelial A549 Cells: The Role of Reactive Oxygen Species. Chemosphere 2014, 100, 42-49. [CrossRef] [PubMed]

34. Klotz, L.O.; Hou, X.; Jacob, C. 1,4-Naphthoquinones: From Oxidative Damage to Cellular and Inter-Cellular Signaling. Molecules 2014, 19, 14902-14918. [CrossRef] 
35. Gurbani, D.; Bharti, S.K.; Kumar, A.; Pandey, A.K.; Ana, G.R.E.E.; Verma, A.; Khan, A.H.; Patel, D.K.; Mudiam, M.K.R.; Jain, S.K.; et al. Polycyclic Aromatic Hydrocarbons and Their Quinones Modulate the Metabolic Profile and Induce DNA Damage in Human Alveolar and Bronchiolar Cells. Int. J. Hyg. Environ. Health 2013, 216, 553-565. [CrossRef]

36. Lavrich, K.S.; Corteselli, E.M.; Wages, P.A.; Bromberg, P.A.; Simmons, S.O.; Gibbs-flournoy, E.A.; Samet, J.M. Investigating Mitochondrial Dysfunction in Human Lung Cells Exposed to Redox-Active PM Components Katelyn. Toxicol. Appl. Pharmacol. 2018, 342, 99-107. [CrossRef]

37. Pizzino, G.; Irrera, N.; Cucinotta, M.; Pallio, G.; Mannino, F.; Arcoraci, V.; Squadrito, F.; Altavilla, D.; Bitto, A. Oxidative Stress: Harms and Benefits for Human Health. Oxid. Med. Cell. Longev. 2017, 2017. [CrossRef]

38. Cavalcanti Chipoline, I.; da Fonseca, A.; da Costa, G.; de Souza, M.; Won-Held Rabelo, V.; de Queiroz, L.N.; de Souza, T.; de Almeida, E.; Alvarez Abreu, P.; Pontes, B.; et al. Molecular Mechanism of Action of New 1,4-Naphthoquinones Tethered to 1,2,3-1H-Triazoles with Cytotoxic and Selective Effect against Oral Squamous Cell Carcinoma. Bioorg. Chem. 2020, $101,103984$. [CrossRef]

39. Fowler, P.; Meurer, K.; Honarvar, N.; Kirkland, D. A Review of the Genotoxic Potential of 1,4-Naphthoquinone. Mutat. Res. Genet. Toxicol. Environ. Mutagen. 2018, 834, 6-17. [CrossRef]

40. Sheng, K.; Lu, J. Typical Airborne Quinones Modulate Oxidative Stress and Cytokine Expression in Lung Epithelial A549 Cells. J. Environ. Sci. Health Part A 2017, 52, 1-8. [CrossRef] [PubMed]

41. Kida, H.; Mucenski, M.L.; Thitoff, A.R.; Le Cras, T.D.; Park, K.S.; Ikegami, M.; Müller, W.; Whitsett, J.A. GP130-STAT3 Regulates Epithelial Cell Migration and Is Required for Repair of the Bronchiolar Epithelium. Am. J. Pathol. 2008, 172, 1542-1554. [CrossRef]

42. Wang, H.; Luo, Y.H.; Shen, G.N.; Piao, X.J.; Xu, W.T.; Zhang, Y.; Wang, J.R.; Feng, Y.C.; Li, J.Q.; Zhang, Y.; et al. Two Novel 1,4-Naphthoquinone Derivatives Induce Human Gastric Cancer Cell Apoptosis and Cell Cycle Arrest by Regulating Reactive Oxygen Species-Mediated MAPK/Akt/STAT3 Signaling Pathways. Mol. Med. Rep. 2019, 20, 2571-2582. [CrossRef] [PubMed]

43. Ema, M.; Miyawaki, E.; Harazono, A.; Kawashima, K. Developmental Toxicity Evaluation of Phthalic Acid, One of the Metabolites of Phthalic Acid Esters, in Rats. Toxicol. Lett. 1997, 93, 109-115. [CrossRef]

44. Kwack, S.J.; Lee, B.M. Comparative Cytotoxicity and Sperm Motility Using a Computer-Aided Sperm Analysis System (CASA) for Isomers of Phthalic Acid, a Common Final Metabolite of Phthalates. J. Toxicol. Environ. Health Part A Curr. Issues 2015, 78, 1038-1050. [CrossRef] [PubMed]

45. Suzukawa, M.; Komiya, A.; Koketsu, R.; Kawakami, A.; Kimura, M.; Nito, T.; Yamamoto, K.; Yamaguchi, M. Three Cases of Ortho-Phthalaldehyde-Induced Anaphylaxis after Laryngoscopy: Detection of Specific IgE in Serum. Allergol. Int. 2007, 56, 313-316. [CrossRef] [PubMed]

46. Horikiri, M.; Park, S.; Matsui, T.; Suzuki, K.; Matsuoka, T. Ortho-Phthalaldehyde-Induced Skin Mucous Membrane Damage from Inadequate Washing. BMJ Case Rep. 2011, 2011, bcr0220102709. [CrossRef] 